\title{
PENGARUH KUALITAS PELAYANAN TERHADAP LOYALITAS PASIEN UMUM RSUD SUNGAI DAREH DENGAN KEPUASAAN PASIEN SEBAGAI VARIABEL INTERVENING
}

\author{
Indah Zil Arsy S, Henryanto Abaharis \\ Sekolah Tinggi Ekonomi KBP \\ indahzilarsy34@gmail.com
}

\begin{abstract}
This study aims to find out and analyze how much influence Quality of Service $(X)$ consists of 5 research variables namely Tangible, Reliability, Responsiveness, Assurance and Emphaty on patient loyalty $(Y)$ with satisfaction $(z)$ in the dareh River Hospital, using the method Data collection is in the form of a questionnaire of 100 respondents. In analyzing the data using validity, reliability, and classic assumption tests, namely normality, multicollinearity and heteroscedasticity. The analytical method used is multilevel linear regression analysis. While for testing the hypothesis, namely the F test, $T$ test, R2 determinant coefficient and path analysis test (Path analysis) using SPSS tools. The results showed that the Tangible variable had no effect on patient loyalty in Sungai dareh Hospital, Reliability variable did not affect the loyalty of Sungai dareh Hospital, the responsiveness variable did not affect patient loyalty in the Sungai dareh Hospital Assurance variable did not affect patient loyalty in RSUD Sungai dareh variables Empathy has no effect on patient loyalty in Sungai dareh Hospital. Based on the results of multilevel linear regression testing, it was found that Service Quality variables consisting of Tangible, Reliability, Responsiveness, Assurance and Empathy did not have a significant effect on patient loyalty.
\end{abstract}

Keywords: Service quality, patient satisfaction, patient loyalty

\section{PENDAHULUAN}

Kesehatan merupakan kebutuhan yang sangat penting untuk masyarakat. Meningkat status sosial masyarakat pada saat ini mempengaruhi tuntutan masyarakat akan kualitas pelayanan penyedia jasa kesehatan semakin meningkat pula. Hal ini menuntut para penyedia jasa pelayanan kesehatan selalu meningkatkan kualitas pelayanannya untuk lebih baik lagi. Bagi penyedia jasa kesehatan tidaklah hal yang mudah untuk bisa memberikan pelayanan serta kualitas pelayanan yang baik karena pelayanan yang diberikan oleh penyedia jasa kesehatan secara langsung dirasakan oleh pasien sehingga bila terdapat sedikit kelalaian dalam menangani pasiennya dapat berdampak buruk bagi pasien dan bagi penyedia jasa kesehatan itu sendiri.Oleh sebab, tingkat kepuasaan penerima layanan dapat diukur dari keberhasilan penyedia pelayanan kesehatan. Kepuasan penerima layanan dicapai apabila (Wigati, 2008).

Rawat inap (opname) yaitu perawatan pasien karena penyakit tertentu yang ditangani oleh ahli tenaga medis yang berada pada penyedia layanan jasa kesehatan.Pasien tersebut diinapkan di ruangan yang berada di rumah 
sakit guna mendapat perawatan yang lebih baik.Ruang inap adalah sebuah tempat pasien dirawat dan mendapatkan perawatan dari tenaga medis.Menurut Trimumpuni dalam penelitian (Dewi, 2016) rawat inap adalah salah satu pelayanan yang ada di suatu rumah sakit untuk merawat pasien.

Setiap pasien menginginkan pelayanan kesehatan yang baik karena pelayanan kesehatan karenasalah satu kebutuhan setiap orang.Kualitas jika pelayananyang ditawarkan terhadap pelanggan sesuai yang di idamkan jadiakan memberikan kepuasan. Namun untuk memperoleh tingkat kepuasan sesuai dengannyajadi kualitas pelayanan harus terus ditingkatkan dan diperbaiki. Menurut Lupiyoadi dalam penelitian (Dewi, 2016) Signifikasi loyalitas pelanggan sangat berhubungan dengan kelangsungan perusahaan dan terhadap kuatnya pertumbuhan perusahaan di masa yang akan datang. Namun pasien yang setia seperti aset bagi rumah sakit dimana dapat pasien akan datang kembali ketika kesehatannya terganggu juga akan memberikan efek yang sangat baik bagi rumah sakit ketika ada isu yang tidak enak didengar, biasanya pasien yang setia menjadi menyangkal dan memberi berita yang jelas namun nama baik rumah sakit tetap terjaga. Pasien yang loyal dan puas terhadap pelayanan rumah sakit pastinya akan memberitahukan ke setiap orang ketika mereka membutuhkan atau mencari rumah sakit yang bisa dalam hal dan bekerja sama dengan BPJS Menurut (Tjiptono (2011).

Bahwa keuntungan lain dari loyalitas yaitu menurunkan biaya pemasaran.Pemenuhan Dengan sebab itu hak atas jaminan sosial adalah hak konstitusional setiap seluruh rakyat Indonesia yang mesti dipenuhi oleh negara. Pelayanan serta kualitas pelayanan yang bagussebab pelayanan yang di lakukanterhadap penyedia jasa kesehatan secara langsung dinikmati oleh pasien sehingga bila terdapat sedikit kelalaian dalam menangani pasiennya dapat berpengaruh buruk bagi pasien dan bagi penyedia jasa kesehatan itu sendiri.Maka dari itu, tingkat kepuasaan penikmat layanan dapat dinilai dari keberhasilan penyedia pelayanan kesehatan.

Kepuasan penerima layanan dipenuhi apabila penerima di peruntukan bagi pasien yang mempunyai banyak uang, sedangkan pasien yang tidak mampu tidak mendapatkan perawatan yang baik(Efyou, 2011). Melayani pelayanan yang bagus untuk pasienn merupakan tuntutan pemberi jasa pelayanan kesehatan. Bagi mereka yang memerlukan pelayanan kesehatanpasti akan mencari penyedia layanan kesehatan yang bagus dan dapat memberikan kepuasaan bagi mereka (Assauri, 2003).

Permasalahan dengan berkaitan dengan loyalitas pasien yang harus diperhatikan dengan penyedia layanan jasa kesehatan merupakankualitas layanan dengan melihat peralatan dan perlengkapan fisik, kemampuan dalam melayani pelayanan kesehatan, kecepatan dalam memberikan pelayanan, jaminan dan kepastian serta empati yang diperuntukkan untuk pasien sehingga mencptkan pelayanan kepuasan pasien. Pada saat ini pengguna jasa pelayanan kesehatan khususnya yang memakai kualitas pelayanan umum tidak ingin melihat hasil akhirnya yang berupa kesembuhan, tetapi mereka juga menilai apa yang mereka lihat dan rasakan selama perawatan.

Berhubungan dengan permasalahan tersebut, jadi penyedia layanan kesehatan.Tidak bisa bertindak semaunya sendiri, dan tidak membeda- 
bedakan pelayanan berdasarkan status sosial tetapi harus dapat menciptakan kepercayaan, pelayanan, dan komitmen yang baik untuk pengguna layanan kesehatan sehingga terjadi pada kepuasaan dan loyalitas pengguna layanan kesehatan tersebut.

Tujuan penelitian ini merupakan menganalisis pengaruh kualitas pelayanan terhadap loyalitas pasien pengguna pelayana umum terhadap kepuasan pasien RSUD Sungai Dareh. Tidak dapat bertindak semaunya sendiri, namun harus dapat menciptakan kepercayaan, pelayanan, dan komitmen yang baik dengan pengguna layanan kesehatan sehingga menimbulkan pada kepuasaan dan loyalitas pengguna layanan kesehatan tersebut

\section{Tabel 1}

\section{Data Pasien Umum RSUD Sungai Dareh}

$\begin{array}{llcc}\text { No } & \text { Tahun } & \text { Umum } & \text { Keteranagan } \\ 1 . & 2014 & 5741 & \text { Meningkat } \\ 2 . & 2015 & 4767 & \text { Menurun } \\ 3 . & 2016 & 4563 & \text { Menurun } \\ 4 . & 2017 & 7552 & \text { Meningkat }\end{array}$

\section{Sumber: RSUD Sungai Dareh}

Berdasarkan Tabel Di atas terlihat data di tahun 2014 berjumlah 5.741 sehingga Pasien meningkat.di tahun 2015 terdapat 4.767 pasien dan data 2016 terdapat berjumlah 4.563 pasien mengalami penurunana kembali. Namun di tahun 2017 mengalami peningkatan yang cukup besar berjumlah 7.552 pasien.Apakah yang menyebakan penurunan yang di tahun 2015 dan 2016dan peningkatankembali di tahun 2017 di RSUD Sungai Dareh.

Mempertahankan loyalitas konsumen perlu untuk selalu meningkatkan kualitas produk.Loyalitas konsumen bisa dipengaruhi oleh beberapa faktor yaitu kualitas produk. Kualitas produk yaitu sekumpulan ciri dan karakteristik dari barang dan jasa yang mempunyai keahlian untuk melengkapi kebutuhan, ketepatan, kemudahan, pemeliharaan, serta perlengkapan-perlengkapan lainnya dari suatu produk (Widjoyo et al., 2014).

Terjadinya kenaikan tiap tahunnya pasien pasien pengguna pelayanan Umum di Rumah sakit, apakah pelayanan yang di berikan rumah sakit semakin baik daritiap tahun nya namun, berpengaruh terhadap kepuasan dan loyal pasien terhadap rumah sakit. Oleh sebab itu peneliti tertarik ingin mengetahui sejauh mana kualitas pelayanan yang di berikan terhadap pengguna pelayanan Umum.Perbedaan dalam penelitian ini dengan penelitian yang peneliti dilakukan merupakan penelitian. intervening sebagai motivasi Pasien, Sedangkan yang peneliti lakukan intervening sebagai kepuasan Pasien. Berdasarkan penelitian ini peneliti tertarik mengambil judul "Pengaruh Kualitas Pelayanan Umum terhadap Loyalitas Pasien RSUD Sungai Dareh dengan Kepuasan Pasien sebagai Variabel Intervening . Rumusan Masalah 
Adapun masalah yang diambil dalam penelitian ini yaitu :

1. Apakah Tangible berpengaruh terhadap loyalitas pasien pada Rumah Sakit RSUD Sungai Dareh?

2. Apakah Reability berpengaruh terhadap loyalitas Pasien pada rumah Sakit RSUD Sungai Dareh?

3. Apakah Responseveness berpengaruh terhadap loyalitas pasien pada Rumah Sakit RSUD Sungai Dareh?

4. Apakah Assurance bepengaruh terhadap loyalitas Pasien pada Rumah Sakit RSUD Sungai Dareh?

5. Apakah Empaty berpengaruh terhadap loyalitas pasienpada Rumah Sakit RSUD Sungai Dareh?

6. Apakah Kepuasaan Berpengaruh terhadap loyalitas terhadap Variabel Intervening?

\section{LANDASAN TEORI \\ Kepuasan}

\section{Pengertian Kepuasaan}

Menurut Schnaars, (2015)berpendapat bahwa pada dasarnya tujuan dari sebuah bisnis adalah dengan menciptakan para pelanggggan yang puas.Terciptanya kepuasan pelanggan bisa memberi beberapa manfaat di antaranya hubungan perusahaan dan pelanggan yang akan menjadi hubungan yang hangat, untuk dasar yang positif bali pembeli ulang dan terbentuknya loyalitas pelanggan, dengan membentuk rekomendasi gethok tukar yang baik yang bermanfaat terhadap perusahaan.

Pengertian Kepuasan Pelanggan Kepuasan yaitu suatu perasaan yang menunjukkan kesenangan atau kecewaan seseorang terhadap kinerja atau produk yang timbul mengukur(Kotler, 2004)

\section{Faktor-faktor mempengaruhi kepuasan}

a. Sistem Keluhan dan Saran, Pada penyedia layanan jasa kesehatan khususnya rumah sakit sistem keluhan dan masukan ini dapatlakukan terhadapcara pihak rumah sakit bisa mempekerjakan staf yang khusus menangani keluhan dan saran dari pasien selain itu bisa juga dengan menyediakan kartu komentar kemudian menempat kotak saran di bagian-bagian tertentu.

b. Ghost Shopping, suatu perusahaan mempekerjakan orang yang diminta untuk menjadi seorang pembeli di perusahaan atau produk pesaing Hasil dari pembelian itu dapat ditarik kesimpulan tentang kelebihan dan kekurangan dari perusahaan produk pesaing guna untuk peningkatan kemampuan dari perusahaan sendiri.

c. Lost Customer Analysis, Bagi para pembeli yang berhenti maupuan bertukar ke perusahaan atau produk lain secara langsung dihubungi dari perusahaan supaya bisa segera diambil kebijakan untuk memperbaikan kelemahanada di perusahaan itu. 
d. Survei Kepuasan Pelanggan, perusahaan bisa melakukan survei langsung kepada pembeli untuk memperoleh respon balik dantanggapan dari pelanggan.(Nursalam, 2011)

Kepuasan pelanggan sebagai suatu beli tergantung pada kinerja produk actual, sehingga sesuai dengan harapan.Pembeli.Maka dapat dideskripsikan bahwa kepuasan pelanggan adalahperasaan senang yang datang terhadap aktivitas yang diterima baik berupa produk atau jasa sesuai yang diharapkan dalam usaha melengkapi kebutuhan pelanggan.Sehingga mempengaruhi perilaku konsumen dan bisa memberikan dampak yang fositifdari perusahaan dan dapatjadikan atau memjadi calon pelanggan yang setia.

Faktor manusia pengaruh sekitar $70 \%$ oleh sebabitu kepuasan dengan kualitas pelayanan payah dilihat untuk di jadikan pedoman oleh perusahan lain.harga yang terjangkauyaitu sumber kepuasan yang sangat pentingsebab mereka akan memperolehvalue of money yang tinggi. Manfaat Kepuasan Pelanggan

Kepuasan pelanggan menjadi sangat penting bagi divisi pemasaran karena dapat menjadi tombak dalam dunia pemasaran karena pelanggan yang setiajadi meluaskan cerita baik sesuai dengan pengalaman yang diterima dan dapat menjadi iklan berjalan dan berbicara bagi suatu perusahaan, dan dapat menurunkan biaya untuk memikat pelanggan baru.

Pelanggan baru akan sangat tertarik ketika sang pemberi berita merasa sangat dipuaskan dan pelayanan setiap perusahaan tersebut sehingga pelanggan baru segera mencoba dengan perusahaan tersebut dan membuktikan terhadap pelayanannya memang begitu mengesankan dan memudahkan bagi pelanggan.

Dan setiap penyedia layanan juga wajib siap sedia dalam menanggapi respon yang kurang baik atau yang baik.Perusahaan yang harus menemukan inovasi-inovasi baru dalam meberikan pelayanan sehingga setiap pelanggan datang bisa menerima sesuatu yang berbeda memberikan pengalaman yang tidak samanamunakan memuaskan dan menjadikan pelanggan baru menjadi loyal dan pelanggan lama tetap setia dan pasti memasarkan perusahaan secara tidak langsung.(Kotler, 2004)

\section{Dimensi Kepuasan Pelanggan}

(Fandy Tjitono,Ph.D.2015)

a. Kinerja (Performance) karakteristik operasi pokok dari yang digunakan konsumen.

b. Ghost Shopping, Suatu perusahaan mempekerjakan orang yang diminta dengan menjadi seorang pembeli di perusahaan atau produk pesaing. Hasil dari pembelian itu bisa ditarik kesimpulan tmengenai kekuatan dan kelamahan dari perusahaan produk pesaing guna untuk menaikkan potensial dari perusahaan sendiri.

c. Lost Customer Analysis, Bagi para pembeli yang berhenti maupuan berganti ke perusahaan atau produk lain secara langsung dihubungi oleh perusahaan supaya dapat segera diambil kebijakan untuk memperbaiki kelemahan yang ada di perusahaan itu. 


\section{Loyalitas}

(Fandy Tjitono,Ph.D.2015)

\section{Pengertian Loyalitas}

Pengertian Loyalitas Pelanggan Pengertian pelanggan yang. Hal ini bahwa jenis-jenispelanggan yangsetia merupakan mereka akan secara berulang-ulang membeli produk atau menggunakan jasa pada perusahaan yang sama,.

Loyalitas pelanggan merupakan janji para pelanggan dalam suatu merek, jasa, took atau pemasok, kategori produk, serta aktivitas. Loyalitas diperlukan untuk menjelaskan kesetiaan para pelanggan untuk terus memakai produk dan jasa pada perusahaan tertentu secara terus menerus dan pelanggan (Christopher, 2005.)

Dimensi Loyalitas Pelanggan Indikator dari loyalitas pelanggan menurut (kotler (2012)yaitu repat membandingkan keyakinan terhadap objek, tindakan, kondisi tertentu.

Jika pelanggan mengatakan kenyamanan merupakanvalue, maka kepuasan yang mereka rasakan akan terjadi apabila pelanggan memperoleh kenyamanan pada saat memakai produk atau jasa. Jika pelanggan menyatakan harga yang terjangkauyaitu value maka kepuasan yang mereka alami akan terjadi apabila pelanggan memperoleh harga yang kompetitif(Irawan, 2003)

Dengan tercapainya sebuah kepuasan pelanggan (customer satisfaction) yang maksimal jadi sebuah perusahaan akanbisa mencapai loyalitas pelanggan. Perusahaan akan memperoleh banyak manfaat dari kepuasan pelanggan, jika kepuasan pelanggan tinggi maka tingkat loyalitas pelanggan akan tinggi pula (Lovelock dan Wright, 2005)

Jika kepuasan pelanggan bisa tercapai maka perusahaan maka mempertahankan pelanggan yang lama dan menarik pelanggan yang baru. Dengan tercapainya sebuah kepuasan pelanggan maka pelanggan tersebut dengan sendirinya akan mempunyai pengalaman yang baik terhadap produk tersebut dan akan menceritakan pengalamannya setiap orang lain untuk berpartisipasi menggunakan produk tersebut sehingga akan menguntungkan bagi perusahaan. Dari beberapa pendapat para ahli diatas dapat disimpulkan yaitu pelanggan dikatakan puas jikavalue yang mereka peroleh dapat memenuhi harapan yang mereka inginkan.

Menurut (Tjiptono (2007)definisi kualitas jasa berfokus pada ketepatan penyampaian untuk menyeimbangkan kemauan pelanggan serta memenuhikebutuhan pelanggan .

\section{Karakteristik Loyalitas}

a. Melakukan dengan pembelian berulang secara teratur.

b. Membeli yang antar lini produk dan jasa.

c. Menjelasakan terhadap kepada orang lain.

d. Memberi tahukandengan kekebalan terhadap tarikan dari perusahaan lain 


\section{Dimensi Loyalitas}

Dimensi Loyalitas Pelanggan Menurut (Lupiyoadi (2013), merumuskan bahwa dimensi loyalitas pelanggan yaitu:

a. Loyalitas atau kesetiaan kepada perusahaan ( Loyalty),

b. Keinginan untuk beralih $\operatorname{produk}($ switch),

c. Keinginan untuk membayar lebih (willingness to pay more),

d. Respon lingkungan eksternal pada penyelesaian masalah (External response to problem),

e. Respons lingkungan internal pada penyelesaian masalah ( Internal response to problem ) Keuntungan Loyalitas.

Dari penjelasaan loyalitas sendiri keuntungannya adalah :

a. Naiknyapembelian ulang,

b. Berkurangnya perpindahahan pelanggan ke pesaing,

c. Promosi secara baik kerabat dan teman-teman,

d. Peningkatanlaba perusahaan.

Dapat diambil kesimpulan bahwa loyalitas pelanggan perusahaan akan melayani keuntungan yang sangat besar tidak hanya kepada profit perusahaan melainkan juga untuk Pengaruh kualitas pelayanan terhadap5 kesejahteraan karyawan karena dapat merasa nyaman dengan keadaan perusahaan sendiri dan akan memberikan pelayanan yang terbaik untuk konsumen. Dan bagi konsumen pasti sangat menyukai jika diberikan pelayanan yang memuaskan dan setiap perusahaan dapat mempelebar market share dan bisa melakukan

Kualitas Pelayanan perluasan produk baik secara tempat maupun jumlah produk.

\section{Pengertian Kualitas Pelayanan}

Pengertian kualitas pelayanan kualitas produk dan jasa didefinisikan sebagai alat yang dipergunakan untuk memenuhi keinginan dan harapan dari pelanggan yang diperolehdari produksi barang atau jasa,pemasaran yang dilakukan perusahaan dan pemeliharaan produk atau jasa tersebut(Wijaya, 2011)

Menurut (Tjiptono (2007)definisi kualitas jasa berfokus pada ketepatan penyampaian untuk menyeimbangkan keinginan pelanggan serta pemenuhan kebutuhan pelanggan yang sesuai.

\section{Karaketistik Kualitas Pelayanan}

Tiga macam karakteristik harapan seorang pelanggan.

a. Will expectatiion yaitu suatu kinerja yang didugabisa diterimanya dengan semua informasi yang diperoleh. Suatumenilai kualitias jasa tertentu karakter ini adalah karakter yang sering digunakan pelanggan.

b. Should expectation, yaitu tingkat kinerja yang dianggap sudah selayaknya diterima pelanggan.

c. Ideal expectation, yaitu tigkat kinerja optimal atau terbaik yang diharapkan dapat diterima pelanggan.

\section{Dimensi Kualiatas Jasa, yaitu:}

Berwujud (tangible), yaitu keahlian perusahaan dalam memngasihkanhambatannya dalam memperoleh produk atau jasa pada pihak lain. 
Reliabilitas, merupakan kemampuan perusahaan produk atau jasa untuk memberikan pelayanan sesuai dengan yang mereka janjikan.Pelayanan harus disesuaikan dengan harapan para pelanggannya seperti pelayanan yang, ketepatan waktu dalam menyalurkan pelayanan, serta tingkat akurasi tinggi.

Ketanggapan (responsiveness), yaitu suatu tindakan yang tanggapdan tepat serta informasi yang jelas dan akurat dalam memberikanpelayanan kepada para pelanggan.

Jaminan dan Kepastian (assurance), yaitucara perusahaan produk atau jasa dalam usaha menciptakan kepercayaan para pelanggan kepada perusahaan dengan pengetahuan yang banyak dan keterampilan para pegawainya

Empati (empathy), merupakan cara perusahaan dalam merupakan kemauan pelanggannya dengan melakukan perhatian yang bersifat privasi yang diberikan kepada para pelanggannya dengan berharap para pelanggan mengetahui bahwa perusahaan memiliki maksu dan pengetahuan mengenai pelanggan serta perusahaan bisa memahami Kualitas pelayanan menurut (Lovelock et al (2010)

Menyimpulkankualitas layanan berbasis pengguna disegerakan dengan premis bahwa kualitas terletak di mata orang yang melihatnya mengartikan ini menyamakan kualitas dengan kepuasan maksimum. Perspektif yang subjektif dan berorientasi pada kebutuhan ini mengakui bahwa pelanggan yang beda memiliki ingin dan kebutuhan yang berbeda pula.

Kesimpulannya yang bisa ditarik dari definisi di atas merupakan setiap orang membutuhkan kebutuhan dan punyakeinginan yang berbeda setiap orangnya tetapi pelanggan tetap berharap memperoleh pelayanan yang sama dengan kualitas yang terbagus. Bagi pemberi layanan juga namun memberikan pelayanan yang sama tidak perlu membeda-bedakan layanan. Biasanya terjadi diantara sikaya dan simiskin

Dan untuk memaksimalkan tingkat kepuasan maksimaljadi kualitas pelayanan wajib terus ditingkat dan diperbaiki. Menurut (Kotler dan Amstrong (2012)mengungkapkan bahwa "Quality is the totally and characteristics of the product and service that bear on its ability to satisfy stated or implied needs" maksud dari definisinya yaitu kualitas merupakan keseluruhandari keistimewaan dan karakteristikdari produkatau jasa yang menunjang kemampuannya.

\section{Dimensi Kualiatas Pelayanan}

Dimensi Kualitas Pelayanan Menurut (Tjiptono, Fandy (2017))mengatakan bahwa ada menilai kualitas pelayanan yaitu,

a. Bukti fisik (Tangible), yaitu tampilan fisik perlengkapan, pegawai, dan sarana komunikasi

b. Keandalan (Reliability), yakni keahlian memberikan pelayanan yang memuaskan.

c. Daya Tangkap (Responsiveness), yaitu keinginan para staf dan karyawan untuk membantu para pelanggan dan memperolehpelayanan secaratanggap. 
d. Jaminan (Asurance) melingkup pengetahuan, kemampuaan, kesopanan dan sifat dapat dipercaya yang dimiliki pada staf, bebas dari bahay, risiko atau keragu-raguan.

e. Emphaty, yaitu kemudahan dalam melakukan hubungan komunikasi yang bagus perhatian pribadi dan mengertikan kebutuhan para pelanggan

\section{Prinsip-Prinsip Kualitas Pelayanan}

Prinsip - Prinsip kualitas pelayanan kualitas pelayanan juga mempunyai prinsip agar pelayan yang diberikan tidak melanggar aturan yang telah ditetapkan. Berikut prinsip kualitas pelayanan (Tjiptono 2011) merupakan:

a. Kepemimpinan.

Strategi kualitas perusahaan harus merupakan inisiatif dan komitmen dari manajemen puncak.Manajemen puncak seharusnya memimin perusahaan untuk naik strategi kinerja kualitasnya tanpa adanya kepemimpinan dari manajemen puncak jadi usaha untuk meningkatkan kualitas pelayanan dari manajemen puncak berdampak kecil terhadap perusahaan.

b. Pendidikan.

Review.

Proses review yaitu satu-satunya alat yang paling efektif bagi manajemen untuk mengubah perilaku organisasional. Proses ini yaitu suatu mekanisme yang menjalin ada perhatian yang konstan dan terus menerus untuk memperolehbertujuan kualitas.

\section{METODE PENELITIAN}

Jenis Penelitian

Jenis penelitian ini merupakan penelitian kuantitatif yaitu satu metode penelitian dimana data penelitian berupa angka-angka dan analis menggunakan statistic (sugiyono,2015). Oleh karena itu data yang digunakan berupa angka, baik itu berupa skor atau nilai, hasil penelitian pada umumnya disertai gambar, grafik table atau yang lainnya.Oleh karena itu Penelitian kuantitatif mengguanakan skala numeric berbasisi pola alur deduktif,dimana untuk menjawab rumus, masalah digunakan konsep atau teoris sehingga dapat di rumuskan hipotesis.Tujuannya yaitu untuk menguji hipotesis yang di tetapkan.

\section{Objek atau Lokasi Penelitian}

Menurut (sugiyono,2015) objek penelitian adalah sasaran ilmiah untuk mendapatkan data dengan tujuan dan kegunaan tertentu sesuatu hal objektif, valid dan realiable tentang suatu hal(variable tertentu). Dengan demikian objek penelitian ditentukan untuk mendapatkan sejumlah data yang akan dialakukan penelitian alamat Pulau punjung $\mathrm{Km} 2$ jalan lintas sumatera kabupaten Dharmasraya Kota Padang, Sumatera Barat, Indonesia.

\section{Populasi dan Sampel}

\section{Populasi}

Akan mana penyidik tertarik (Uber sillahi,2015 )dapat disimpulkan dari subjek atau pun objek yang dimiliki sifat diri, yang berbeda yang bisa diteliti. 
Populasi yang akan di amati dalam penelitian ini adalah Pasien Nasabah pengguna RSUD Sungai Dareh Padang sebanyak 2547 responden.

\section{Sampel}

Sampel adalah sebagiaan dari jumlah dan karakteristik yang dimiliki oleh populasi tersebut (Sugiyono, 2015). Pengambilan sampel dilakukan berdasarkan metode purposive sampling.

Purposive samplingyaitu metode pengambilan sampel yang dilakukan dengan mengambil orang-orang yang terpilih oleh peneliti, yaitu nasabah pada Pasien pengguna RSUD sungai Dareh Sumatera Barat. Untuk menentukan ukuran sampel penelitian dari populasi tersebut dapat digunakan rumus Slovin sebagai berikut:

$\mathrm{n}=\frac{\mathrm{N}}{1+\mathrm{N}(e)^{2}}$

Di mana:

$\mathrm{n}=$ Ukuran sampel

$\mathrm{N}=$ Ukuran populasi

$\mathrm{e}=$ Persen kelonggaran ketidak ketelitian karena kesalahan pengambilan sampel yang dapat di tolerir (10\%)

Berdasarkan rumus di atas, maka jumlah sampel dalam penelitian ini adalah:

$\mathrm{n}=\frac{2547}{1+2547(10 \%)^{2}}$

$\mathrm{n}=\frac{2547}{2548(0,1)^{2}}$

$\mathrm{n}=\frac{2547}{25,48}=99,961=100$

Jadi jumlah sampel dalam penelitian ini adalah 100 orang responden

\section{Jenis dan Sumber Data}

\section{Jenis Data}

a. Data Kualitatif

Data yang dinyatakn dalam bentuk kata-kata atau bukan dalambentuk angka.Data ini biasanya menerangkan karakteristik atau sifat.Data Kualitatif adalah data yang berhubungan dengan kategorisasi, karakteristik berwujud pernyataan atau berupa katakata(Sugiyono,2012)

b. Data Kuantitatif

Data yang dinyatakan dalam bentuk angka merupkan hasil dari perhitungan dan pengukuran.Data kuantitatif adalah data yang berwujud angka-angka. Data ini diperoleh dari pengukuran langsung maupun dari angka-angka yang diperoleh dengan mengubah data kuantitatif menjadi data kualitatif (Sugiyono,2012)

\section{Sumber Data}

a. Data Primer

Merupakan datayangdiperolehsecaralangsung dariobjek yang diteliti.Data sumber primer yaitu sumber data yang langsungmemberikan data kepadapengumpul data (Sugiyono, 2010)

Yaitu merupakan data yang diperoleh dalam bentuk baku dan masih membutuhkan pengelolahan lebih lanjut yang nantinya berupa kuesioner. 
b. Data Sekunder

Pengertian dari data sekunder menurut(Sugiyono 2010) yaitu sumber data yang tidak langsung membrikan data terhadap pengumpul data, contohnya, lewat orang lain atau lewat dokumen. Data sekunder merupakan data yang didapatkan tidak langsung dari pengumpul data, melaikan memperoleh data dari pihak lain atau lewat dokumen yang ada.

\section{Defenisi Operasional Variabel}

Tabel 2

Definisi Operasional

\begin{tabular}{|c|c|c|c|}
\hline Variabel & Definisi & Dimensi & Skala \\
\hline $\begin{array}{l}\text { Loyalitas } \\
\text { Pasien(Y } \\
\text { ) }\end{array}$ & $\begin{array}{l}\text { Janji para pelanggan } \\
\text { dalam } \\
\text { suatumerek,jasa,toko/pe } \\
\text { masok, kategori produk, } \\
\text { serta aktivitas.Loyalitas } \\
\text { digunakan untuk } \\
\text { menggambarkan } \\
\text { kesetiaan para pelanggan } \\
\text { untuk terus } \\
\text { menggunakan produk } \\
\text { atau jasa pada } \\
\text { perusahaan. }\end{array}$ & $\begin{array}{l}\text { 1. Trust, Kepercayaan } \\
\text { 2. Emotion commitment } \\
\text { janji pskikologi } \\
\text { pelanggan } \\
\text { 3. Switching } \\
\text { Lost.tanggapan } \\
\text { pelanggan } \\
\text { 4. Word of Mouth } \\
\text { 5. Prilaku untuk } \\
\text { merekomdasikan } \\
\text { kepada orang lain }\end{array}$ & $\begin{array}{l}\text { Skala } \\
\text { Likert }\end{array}$ \\
\hline $\begin{array}{l}\text { Kualitas } \\
\text { Pelayana } \\
\mathrm{n}(\mathrm{X})\end{array}$ & $\begin{array}{l}\text { Kualitas Pelayanan } \\
\text { Kualitas produk dan jasa } \\
\text { didefinisikan sebagai alat } \\
\text { yang digunakan untuk } \\
\text { memenuhi keinginan dan } \\
\text { harapan dari pelanggan } \\
\text { yang dihasilkan dari } \\
\text { produksi barang atau } \\
\text { jasa. }\end{array}$ & $\begin{array}{l}\text { 1. Berwujud (tangible } \\
\text { 2. Reliabilitas } \\
\text { 3. Ketanggapan } \\
\text { (responsiveness), } \\
\text { 4. Jaminan danKepastian } \\
\text { (assurance), } \\
\text { 5. Empati (empathy), }\end{array}$ & $\begin{array}{l}\text { Skala } \\
\text { Likert }\end{array}$ \\
\hline $\begin{array}{l}\text { Kepuasa } \\
\text { n } \\
\text { Pasien }(Z \\
\text { ) }\end{array}$ & $\begin{array}{l}\text { Pelanggan Kepuasan } \\
\text { adalah suatu perasaan } \\
\text { yang menunjukkan } \\
\text { kesenangan atau } \\
\text { kekecewaan seseorang } \\
\text { terhadap kinerja atau } \\
\text { produk yang muncul } \\
\text { setelah membandingkan } \\
\text { antara persepsi/kesan. }\end{array}$ & $\begin{array}{l}\text { 1. Sistem keluhan dan } \\
\text { saran. } \\
\text { 2. Ghost Shopping } \\
\text { 3. Lost Custmer } \\
\text { 4. Survei } \\
\text { 5. Satisfaction with } \\
\text { promotion } \\
\text { 6. Satisfaction with } \\
\text { supervisor }\end{array}$ & $\begin{array}{l}\text { Skala } \\
\text { Likert }\end{array}$ \\
\hline
\end{tabular}




\section{Teknik Analisis Data}

\section{Uji Instrumen Penelitian}

a. Uji Validitas

Uji Validitas adalah suatu metode pengujian yang dilakukan terhadap isi (content) dari suatu pengujian, dengan tujuan untuk mengukur ketepatan instrumen yang. digunakan dalam suatu penelitian (Sugiono, 2006)

Oleh karena itu, uji validitas merupakan alat ukur ketepatan atau kevalidan dari suatu instrument yang diukur. Dilihat dari tingginya validitas alat ukur maka akan semakin tinggi mengenai apa yang menjadi sasaranya atau menampilkan apa yang harus diukur.

Dapat dilihat dari nilai Corrected Item-Total Correlation masing-masing butir pertanyaan. Suatu butir pertanyaan akan diberinilai valid jika data dariCorrected Item-Total Correlation> 0,300. Uji validitas Sehingga pengambilan keputusan adalah:

1) Jika Corrected Item-Total Correlation > 0,300 maka dimensi tersebut valid.

2) Jika Corrected Item-Total Correlation $<0,300$ maka dimensi tersebut tidak valid.

b. Uji Reliabilitas

Uji reliabilitas merupakan proses pengukuran dengan ketepatan (konsisten) dari suatu instrumen. Pengujian ini dimaksudkan untuk menjamin instrumen yang menggunakan merupakan sebuah, instrumen yang handal,, konsistensi, stabil dan dependibalitas, sehingga bila digunakan berkali-kali dapat menghasilkan data yang sama (Usman, 2003).

Oleh karena itu, uji reliabilitas merupakan melihat tingkat konsistensi dari suatu instrumen yang telah dilakukan pengukuran. Uji reliabilitas dapat dilakukan secara serentak terhadap seluruh butir pertanyaan yang lebih dari satu variabel, namun sebaik mungkin uji reliabilitas dilakukan pada masing-masing variabel pada lermbar kerja berbeda, sehingga dapat diketahui konstruksi variabel dikatakan baik memiliki nilai Cronbach's Alpha $>0,60$. Salah satu pengambilan keputusanreliabilitas adalah :

1) Jika Cronbach's Alpha positif, serta Cronbach's Alpha $>0,60$ maka dimensi tersebut reliabel.

2) Jika Cronbach's Alpha negatif, serta Cronbach's Alpha <0,60 maka dimensi tersebut tidak reliabel.

c. Uji TCR (Tingkat Capaian Responden)

Pengujian ini bertujuan untuk menggambarkan karakteristik masing-masing dari variabel penelitian.Dengan melakukan menyajikan data ke dalam tabel distribusi frekuensi, menghitung rata-rata, skor total, dan tingkat pencapaian responden (TCR) serta menginterpretasikannya.Analisis ini tidak hubungkan satu variabel dengan variabel lainnya dan tidak bandingkan satu variabel dengan variabel lainnya.Untuk mencari tingkat mengakuratkan jawaban 
responden digunakan rumus:

$$
T C R=\frac{\text { rata }- \text { rata }}{s t_{t}}
$$

Pengkatagorian nilai mencapai responden digunakan klasifikasi (Fridayani, 2012) sebagai, berikut:

Tabel 3

Rentang Skala TCR

\begin{tabular}{|c|c|c|}
\hline No & Angka & Keterangan \\
\hline 1 & $81 \%-100 \%$ & Sangat Baik \\
\hline 2 & $61 \%-80 \%$ & Baik \\
\hline 3 & $41 \%-60 \%$ & Netral \\
\hline 4 & $21 \%-40 \%$ & Kurang Baik \\
\hline 5 & $0 \%-20 \%$ & Sangat Tidak Baik \\
\hline
\end{tabular}

\section{Uji Asumsi Klasik}

a. Uji Normalitas

Pengujian normalitas ialah pengujian tentang kenormalan distribusi data (Budi Purbayu Santosa dan Ashari, 2005). Dilakukannya Pengujian normalitas merupakan untuk mengetahui sebuah data berdistribusi normal atau tidak. Dalam pengujian ini menggunakan indikator uji Kolmogrov-smirnov terhadappedoman sebagai berikut :

1) Jika nilai probabilitas $>0,05$ maka Ho diterima

2) Jika nilai probabilitas $<0,05$ maka Ho ditolak

Pengujian ini dilakukan untuk menentukan apakah Ho diterima atau ditolak dengan melihat nilai probabilitasnya dan membandingkannya dengan nilai alpha (jika nilai probabilitas $>0,05$ maka Ho diterima dan jika nilai probabilitas $<0,05$ maka Ho ditolak).

b. Uji Multikolinearitas

Uji multikolinearitas adalah pengujian yang dilakukan untuk mengetahui apakah terdapat hubungan yang baikantara beberapa variabel atau semua variabel independen (Mudrajad Kuncoro, 2001). Tujuanuji multikolinieritas adalah untuk melihat apakah pengaruh dari model regresi yang ditemukan korelasi antar variabel independent. Model regresi yang baik adalah tidak terjadi korelasi di antara bebas variabel sehingga bebas dari gejala multikolinearitas (Ghozali, 2001). Kriteriapengujian multikolinearitas adalah sebagai berikut:

1) Tolerance $>0.1$

2) Variance Inflation Factor (VIF) $<10$

Apabila nilaiTolerance $>0.1$ dan Variance Inflation Factor (VIF) < 10, maka tidak terjadi gejala multikonearitas. Sehingga tidak adanya pengaruh antara variable yang satu dengan 
variabel yang lainnya.

c. Uji Linieritas

Uji Linearitas adalah untuk mengetahui hubungan antara variabel bebas dan variabel terikat linear atau tidaknya.Uji linieritas biasanya digunakan sebagai pe rasyarat dalam menganalisis korelasi atau regresi linear. Pengujian pada SPSS dengan menggunakan test of linearity dengan nilai signifikan 0,05 . Jika dua buah variabel dikatakan mempunyai hubungan linearitas bila signifikan lebih dari 0,05 (Ghozali, 2011).

Uji ini apabila nilai signifikan dari kedua variabel yang di uji melalui test of linearity lebih dari 0,05, maka hubungan kedua variabel mempunyai hubungan linieritas.

d. Uji Heteroskedastisitas

Uji heteroskedastisitas yaitu uji yang digunakan untuk melihat apakah dalam model regresi terjadi ketidaksamaan variiance dari residual satu pengamatan ke pengamatan yang lain. Jika variance dari residual satu pengamatan ke pengamatan lain bernilai tetap, maka disebut homoskedastisitas dan jika berbeda disebut heteroskedastisitas. Model koefisien regresi yang sangat baik adalah yang tidak terjadigejala heteroskedastisitas. Jika pvalue $>0,05$ tidak signifikan berarti tidak terjadi heteroskedastisitas artinya model regresi lolos uji heteroskedastisitas (Ghozali, 2013).

Oleh karena itu, apabila jika pvalue $>0,05$, maka tidak terjadi gejala heteroskedastisitas.

\section{Analisis Regresi Bertingkat}

Analisis regresi bertingkat adalah analisis regresi yang digunakan untuk menganalisa pengaruh moderasi (Ellitan, 2005). Dalam penelitian analisis regresi bertingkat digunakan untuk mengetahui kualitas pelayanan pengaruh intervening kepuasan terhadap loyalitas Pasien.

Adapun persamaan dalam penelitian ini adalah:

$$
\begin{aligned}
\mathrm{Y}=\alpha+\beta_{1} \mathrm{X}_{1}+\beta_{2} \mathrm{X}_{2}+\beta_{3} \mathrm{X}_{3}+\beta_{4} \mathrm{X}_{4}+\beta_{5} \mathrm{X}_{5}+\beta_{1} \mathrm{X}_{1} * \mathrm{Z}+\beta_{2} \mathrm{X}_{2} * \mathrm{Z}+\mathrm{B}_{3} \mathrm{X}_{3} * \mathrm{Z}+ \\
\beta_{4} \mathrm{X}_{4} * \mathrm{Z}+\beta_{5} \mathrm{X}_{5} * \mathrm{Z} \\
\mathrm{Y}=\text { Loyalitas Pasien } \\
\alpha=\text { Koefisien Konstanta } \\
\beta_{1}=\text { Koefisien Regresi untuk Reliability } \\
\beta_{2}=\text { Koefisien Regresi untuk Responsiveness } \\
\beta_{3}=\text { Koefisien Regresi untuk Empaty } \\
\beta_{4}=\text { Koefisien Regresi untuk Assurance } \\
\beta_{5}=\text { Koefisien Regresi untuk Tangible } \\
\mathrm{X}_{1}=\text { Reliability } \\
\mathrm{X}_{2}=\text { Responsiveness } \\
\mathrm{X}_{3}=\text { Empaty } \\
\mathrm{X}_{4}=\text { Assurance } \\
\mathrm{X}_{5}=\text { Tangible } \\
\mathrm{Z}=\text { Kepuasan }
\end{aligned}
$$




\section{Uji Hipotesis}

a. Goodness Of Fit (F Statistik atau F Test)

Uji statistik $F$ digunakan untukmengetahui apakah yang akan semua variabel dengan independen yang dimasukkan dalam model mempunyai pengaruh secara bersentak terhadap variabel dependen. Untuk menguji hipotesis dengan uji f ini dapat digunakan kriteria sebagai berikut:

1) Quick look, apabila nilai $F$ lebih besar daripada 4 maka Ho dikatakan ditolak pada derajat kepercayaan 5\%, dengan kata lain kita menerima hipotesis alternatif, yang dengan menyebutkan bahwa jika semua, variabel independen secara serentak dan signifikan mempengaruhi variabel dependen.

2) Membandingkan nilai $F$ hasil yang di perhitungan dengan nilai $\mathrm{F}$ menurut tabel., Bila nilai $\mathrm{F}$ hitung lebih besar daripada nilai $\mathrm{F}$ tabel maka Ho ditolak dan Ha diterima.

b. T-Test (Uji t statistik)

Imam Ghozali (2013:98) menyatakan bahwa dalam uji statistik $t$ dasarnya adalah untuk mengetahui seberapa baik pengaruh satu variabel independen secara perorangan dalam menjelaskan variabel dependen. Pengujian t statistik didapatkan dengan menggunakan signifikan level 0,05 ( $\alpha=5 \%)$.

1. Jika nilai signifikan $>0,05$ maka hipotesis ditolak (koefisien regresi bernilai negatif). Ini dinyatakan secara parsial variabel independen tidak memiliki pengaruh negatif dan signifikan terhadap variabel dependen.

2) Jika nilai signifikan $\leq 0,05$ maka di hipotesis diterima (koefisien regresi bernilai positif). Ini dinyatakan secara parsial variabel independen memiliki pengaruh yang positif dan signifikan terhadap variabel dependen.

c. Koefisien determinasi $\left(\mathrm{R}^{2}\right)$

Pengujian koefisien determinasi intinya adalahuntuk melihat seberapa jauh kemampuan model dalam menjelaskan variasi variabel dependen.Nilai koefisien determinasi yang didapatkan antara nol dan satu. Jika niilai $\mathrm{R}^{2}$ yang didapatkan bernilai kecil berarti kemampuan variabel-variabel independen dalam menjelaskan variasi variabel dependen sangat terbatas.

Nilai yang terdekat dengan satu dinyatakan bahwa variabel independen dapat menghasilkan hampir semua informasi yang diperlukan untuk melihat variasi variabel dependen. Penelitian Gujarati (2003) yang dikutip dari penelitian Imam Ghozali (2013:97) meneliti bahwa jika dalam uji empiris didapat nilai adjusted $\mathrm{R} 2$ negatif, maka nilai adjusted $\mathrm{R}^{2}$ dikatakan bernilai nol. Dalam penelitian Secara sistematis jika nilai $R^{2}=1$, maka nilai adjusted $\mathrm{R}^{2} \mathrm{R}^{2}=1$ sedangkan jika nilai $\mathrm{R}^{2}=0$, maka adjusted $R^{2}=(1-k) /(n-k)$. Jika $k>1$, maka adjusted $R^{2}$ akan bernilai negative. 
PEMBAHASAN

Uji Regresi Bertingkat

Analisis Regresi Linear Tahap I

\section{Tabel 3}

\section{a. Reliability}

Hasil Uji Regresi Linear Tahap I

Coefficients $^{\mathrm{a}}$

\begin{tabular}{|c|c|c|c|c|c|c|}
\hline \multirow{2}{*}{\multicolumn{2}{|c|}{ Model }} & \multicolumn{2}{|c|}{$\begin{array}{c}\text { Unstandardized } \\
\text { Coefficients }\end{array}$} & \multirow{2}{*}{\begin{tabular}{|c|}
$\begin{array}{c}\text { Standardized } \\
\text { Coefficients }\end{array}$ \\
Beta \\
\end{tabular}} & \multirow[b]{2}{*}{ 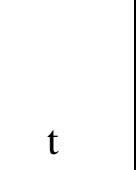 } & \multirow[b]{2}{*}{ Sig. } \\
\hline & & $\mathrm{B}$ & Std. Error & & & \\
\hline 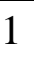 & (Constant) & 17.562 & 1.529 & & 11.487 & .000 \\
\hline & $\mathrm{X} 1$ & -.014 & .119 & -.012 & -.121 & .904 \\
\hline
\end{tabular}

a. Dependent Variable: Y

Berdasarkan hasil analisis regresi linear tahap I diperoleh persamaan sebagai berikut:

$\mathrm{Y}=\alpha+\beta_{1} \mathrm{X}_{1}+\mathrm{e}$

Persamaan regresi berganda diatas dapat diartikan bahwa:

1) Nilai konstanta variabel $X_{1}$ yaitu17,562 dengan parameter positif yang mana dapat disimpulkan bahwa nilai Loyalitas adalah sebesar dengan17,562 asumsi variabel lain bernilai nol.

2) Nilai koefisien regresi Reliability yaitu -014 dengan parameter negatif yang mana dapat disimpulkan bahwa setiap peningkatan satu kesatuan Reliability maka akan mengakibatkan penurunan nilai koefisien Loyalitas sebesar 014.

b. Responsivenes

Coefficients $^{\mathrm{a}}$

\begin{tabular}{|c|c|c|c|c|c|c|}
\hline \multirow{2}{*}{\multicolumn{2}{|c|}{ Model }} & \multicolumn{2}{|c|}{$\begin{array}{c}\text { Unstandardized } \\
\text { Coefficients }\end{array}$} & \multirow{2}{*}{$\begin{array}{c}\text { Standardized } \\
\text { Coefficients } \\
\text { Beta }\end{array}$} & \multirow[b]{2}{*}{$\mathrm{t}$} & \multirow[b]{2}{*}{ Sig. } \\
\hline & & B & Std. Error & & & \\
\hline 1 & (Constant) & 17.045 & 1.450 & & 11.752 & .000 \\
\hline & $\mathrm{X} 2$ & .026 & .112 & .024 & .234 & .816 \\
\hline
\end{tabular}

Sumber: Data Primer diolah dengan SPSS Th.2018

Berdasarkan hasil analisis regresi linear tahap I diperoleh persamaan sebagai berikut:

$Y=\alpha+\beta_{2} X_{2}+e$

Persamaan regresi berganda diatas dapat diartikan bahwa:

1) Nilai konstanta variabel $X_{2}$ yaitu17.045 dengan parameter positif yang mana dapat disimpulkan bahwa nilai Loyalitas adalah sebesar 17.045 dengan asumsi variabel lain bernilai nol.

2) Nilai koefisien regresi Responsivenes yaitu 026 dengan parameter negatif yang mana dapat disimpulkan bahwa setiap 
peningkatan satu kesatuan Responsivenes maka akan mengakibatkan penurunan nilai koefisien Loyalitas sebesar 026

\section{c. Emphaty}

Coefficients $^{\mathrm{a}}$

\begin{tabular}{|c|c|c|c|c|c|c|}
\hline \multirow{2}{*}{\multicolumn{2}{|c|}{ Model }} & \multicolumn{2}{|c|}{$\begin{array}{c}\text { Unstandardized } \\
\text { Coefficients }\end{array}$} & \multirow{2}{*}{$\begin{array}{c}\begin{array}{c}\text { Standardized } \\
\text { Coefficients }\end{array} \\
\text { Beta }\end{array}$} & \multirow[b]{2}{*}{$\mathrm{t}$} & \multirow[b]{2}{*}{ Sig. } \\
\hline & & B & Std. Error & & & \\
\hline 1 & (Constant) & 17.273 & 1.661 & & 10.396 & .000 \\
\hline & X3 & .008 & .129 & .007 & .065 & .948 \\
\hline
\end{tabular}

Sumber: Data Primer diolah dengan SPSS Th.2018

Berdasarkan hasil analisis regresi linear tahap I diperoleh persamaan sebagai berikut:

$\mathrm{Y}=\alpha+\beta_{3} \mathrm{X}_{3}+\mathrm{e}$

Persamaan regresi berganda diatas dapat diartikan bahwa:

1) Nilai konstanta variabel $X_{5}$ yaitu 17.273 dengan parameter positif yang mana dapat disimpulkan bahwa nilai Loyalitas adalah sebesar 17.273 dengan asumsi variabel lain bernilai nol.

2) Nilai koefisien regresi Emphaty yaitu 0,080 dengan parameter positif yang mana dapat disimpulkan bahwa setiap peningkatan satu kesatuan Emphaty maka akan mengakibatkan kenaikan nilai koefisien Loyalitas sebesar 0,080.

d. Assurance

\section{Coefficients $^{\mathrm{a}}$}

\begin{tabular}{|c|c|c|c|c|c|c|}
\hline \multirow{2}{*}{\multicolumn{2}{|c|}{ Model }} & \multicolumn{2}{|c|}{$\begin{array}{l}\text { Unstandardized } \\
\text { Coefficients }\end{array}$} & $\begin{array}{l}\text { Standardized } \\
\text { Coefficients }\end{array}$ & \multirow[b]{2}{*}{$\mathrm{T}$} & \multirow[b]{2}{*}{ Sig. } \\
\hline & & B & Std. Error & Beta & & \\
\hline 1 & (Constant) & 18.784 & 1.314 & & 14.293 & .000 \\
\hline & $\mathrm{X} 4$ & -.112 & .103 & -.109 & -1.084 & .281 \\
\hline
\end{tabular}

Sumber: Data Primer diolah dengan SPSS Th.2018

Berdasarkan hasil analisis regresi linear tahap I diperoleh persamaan sebagai berikut:

$\mathrm{Y}=\alpha+\beta_{4} \mathrm{X}_{4}+\mathrm{e}$

Persamaan regresi berganda diatas dapat diartikan bahwa:

1) Nilai konstanta variabel $X_{4}$ yaitu18.784 dengan parameter positif yang mana dapat disimpulkan bahwa nilai Loyalitas adalah sebesar 18.784 dengan asumsi variabel lain bernilai nol.

2) Nilai koefisien regresi Assurance yaitu-112 dengan parameter positif yang mana dapat disimpulkan bahwa setiap peningkatan satu kesatuan Assurance maka akan mengakibatkan kenaikan nilai koefisien Loyalitas sebesar112 . 


\section{e. Tangible}

\section{Coefficients $^{\mathrm{a}}$}

\begin{tabular}{|c|c|c|c|c|c|c|}
\hline \multirow{2}{*}{\multicolumn{2}{|c|}{ Model }} & \multicolumn{2}{|c|}{$\begin{array}{c}\text { Unstandardized } \\
\text { Coefficients }\end{array}$} & \multirow{2}{*}{$\begin{array}{c}\text { Standardized } \\
\text { Coefficients } \\
\text { Beta }\end{array}$} & & \multirow[b]{2}{*}{ Sig. } \\
\hline & & B & Std. Error & & & \\
\hline 1 & (Constant) & 17.881 & 1.502 & & 11.904 & .000 \\
\hline & $\mathrm{X} 5$ & -.039 & .117 & -.034 & -.337 & .737 \\
\hline
\end{tabular}

Sumber: Data Primer diolah dengan SPSS Th.2018

Berdasarkan hasil analisis regresi linear tahap I diperoleh persamaan sebagai berikut:

$\mathrm{Y}=\alpha+\beta_{5} \mathrm{X}_{5}+\mathrm{e}$

Persamaan regresi berganda diatas dapat diartikan bahwa:

1) Nilai konstanta variabel $X_{5}$ yaitu17.881 dengan parameter positif yang mana dapat disimpulkan bahwa nilai Loyalitas adalah sebesar 17.881 dengan asumsi variabel lain bernilai nol.

2) Nilai koefisien regresi Tangible yaitu -0,39 dengan parameter positif yang mana dapat disimpulkan bahwa setiap peningkatan satu kesatuan Tangible maka akan mengakibatkan kenaikan nilai koefisien Loyalitas sebesar 0,39 .

\section{Analisis Regresi Linear Tahap II}

Analisis Regresi tahap ke II (Dua) adalah analisis regresi yang digunakan untuk menganalisa pengaruh moderasi. Dalam penelitian ini analisa regresi tahap II digunakan untuk menganalisaintervening pengaruhkualitas pelayan terhadap loyalitas Pasien dengan kepuasaan Pasien Adapun teknik yang digunakan dalam analisis regresi bertingkat yaitu teknik intervening Regresion Analysis atau MRA.

\section{Tabel 4}

\section{A. Reliability}

\section{Hasil Uji Regresi Linear Tahap II}

\begin{tabular}{|c|c|c|c|c|c|c|}
\hline \multicolumn{7}{|c|}{ Coefficients $^{\mathrm{a}}$} \\
\hline \multirow{2}{*}{\multicolumn{2}{|c|}{ Model }} & \multicolumn{2}{|c|}{$\begin{array}{c}\text { Unstandardized } \\
\text { Coefficients }\end{array}$} & \multirow{2}{*}{\begin{tabular}{|c|}
$\begin{array}{c}\text { Standardized } \\
\text { Coefficients }\end{array}$ \\
Beta \\
\end{tabular}} & \multirow[b]{2}{*}{$\mathrm{T}$} & \multirow[b]{2}{*}{ Sig. } \\
\hline & & $\mathrm{B}$ & Std. Error & & & \\
\hline 1 & (Constant) & 17.224 & 1.263 & & 13.642 & .000 \\
\hline & $\begin{array}{l}\text { Interaksi X1 * } \\
\mathrm{Z}\end{array}$ & .000 & .003 & .013 & .125 & .900 \\
\hline
\end{tabular}

Sumber: Data Primer diolah dengan SPSS Th.2018

Berdasarkan hasil analisis regresi linear tahap II diperoleh persamaan sebagai berikut:

$$
\begin{aligned}
& Y=\alpha+\beta_{1} X_{1} * Z \\
& Y=19,838+0,063 X_{1} * Z
\end{aligned}
$$


Dari persamaan variabel moderasi diketahui nilai t hitung interaksi Reliability dengan Kepuasan sebesar 0,125 dengan nilai signifikan yaitu 0,900. Dapat disimpulkan bahwa variabel Kepuasanmemperkuat hubungan antara Reliability dengan Loyalitas Pasien.

\section{B. Responsivenes}

\section{Coefficients $^{\mathrm{a}}$}

\begin{tabular}{|c|c|c|c|c|c|c|}
\hline \multirow{2}{*}{\multicolumn{2}{|c|}{ Model }} & \multicolumn{2}{|c|}{$\begin{array}{c}\text { Unstandardized } \\
\text { Coefficients }\end{array}$} & $\begin{array}{c}\text { Standardized } \\
\text { Coefficients }\end{array}$ & \multirow[b]{2}{*}{$\mathrm{T}$} & \multirow[b]{2}{*}{ Sig. } \\
\hline & & B & Std. Error & Beta & & \\
\hline 1 & (Constant) & 16.908 & 1.173 & & 14.419 & .000 \\
\hline & $\begin{array}{l}\text { Interaksi X2 * } \\
\mathrm{Z}\end{array}$ & .001 & .003 & .041 & .411 & .682 \\
\hline
\end{tabular}

Sumber: Data Primer diolah dengan SPSS Th.2018

Berdasarkan hasil analisis regresi linear tahap II diperoleh persamaan sebagai berikut:

$$
\begin{aligned}
& Y=\alpha+\beta_{2} X_{2} * Z \\
& Y=2,658+0,000 X_{2} * Z
\end{aligned}
$$

Dari persamaan variabel moderasi diketahui nilai t hitung interaksi Responsivenes dengan Kepuasan sebesar -0,041 dengan nilai signifikan yaitu 0,682. Dapat disimpulkan bahwa variabel Kepuasan memperlemah hubungan antara Responsivenes dengan Loyalitas Pasien.

\section{Emphaty}

\begin{tabular}{|c|c|c|c|c|c|c|}
\hline \multirow{2}{*}{\multicolumn{2}{|c|}{ Model }} & \multicolumn{2}{|c|}{$\begin{array}{c}\text { Unstandardized } \\
\text { Coefficients }\end{array}$} & \multirow{2}{*}{$\begin{array}{c}\begin{array}{c}\text { Standardized } \\
\text { Coefficients }\end{array} \\
\text { Beta }\end{array}$} & \multirow[b]{2}{*}{$\mathrm{T}$} & \multirow[b]{2}{*}{ Sig. } \\
\hline & & B & Std. Error & & & \\
\hline 1 & (Constant) & 16.856 & 1.419 & & 11.875 & .000 \\
\hline & $\begin{array}{l}\text { Interaksi X3 } \\
* \mathrm{Z}\end{array}$ & .001 & .004 & .038 & .374 & .709 \\
\hline
\end{tabular}

\section{Coefficients $^{\mathrm{a}}$}

Sumber: Data Primer diolah dengan SPSS Th.2018

Berdasarkan hasil analisis regresi linear tahap II diperoleh persamaan sebagai berikut:

$$
\begin{aligned}
& Y=\alpha+\beta_{3} X_{3} * Z \\
& Y=13,314+0,047 X_{3} * Z
\end{aligned}
$$

Dari persamaan variabel moderasi diketahui nilai t hitung interaksi Emphaty dengan Kepuasan sebesar 0,374 dengan nilai signifikan yaitu 0,709. Dapat disimpulkan bahwa variabel Kepuasan mmemperkuat hubungan antara Emphaty dengan Loyalitas Pasien. 
Coefficients $^{\mathrm{a}}$

\begin{tabular}{|c|c|c|c|c|c|}
\hline \multirow[b]{2}{*}{ Model } & \multicolumn{2}{|c|}{$\begin{array}{c}\text { Unstandardized } \\
\text { Coefficients }\end{array}$} & \multirow{2}{*}{\begin{tabular}{|c}
$\begin{array}{c}\text { Standardized } \\
\text { Coefficients }\end{array}$ \\
Beta
\end{tabular}} & \multirow[b]{2}{*}{$\mathrm{T}$} & \multirow[b]{2}{*}{ Sig. } \\
\hline & B & Std. Error & & & \\
\hline (Constant) & 18.059 & 1.136 & & 15.902 & .00 \\
\hline $\begin{array}{l}\text { Interaksi X4 } \\
* \mathrm{Z}\end{array}$ & -.002 & .003 & -.062 & -.610 & \\
\hline
\end{tabular}

a. Dependent Variable: Y

Sumber: Data Primer diolah dengan SPSS Th.2018

Berdasarkan hasil analisis regresi linear tahap II diperoleh persamaan sebagai berikut:

$$
\begin{aligned}
& Y=\alpha+\beta_{4} X_{4} * Z \\
& Y=-4,372+-0,027 X_{4} * Z
\end{aligned}
$$

Dari persamaan variabel moderasi diketahui nilai t hitung interaksi Assurance dengan Kepuasan sebesar 0,610 dengan nilai signifikan yaitu 0,543. Dapat disimpulkan bahwa variabel Kepuasan memperlemah hubungan antara Assurance dengan Loyalitas Pasien.

\section{E. Tangible}

\section{Coefficients $^{\mathrm{a}}$}

\begin{tabular}{|l|r|r|r|r|r|}
\hline & \multicolumn{2}{|c|}{$\begin{array}{c}\text { Unstandardized } \\
\text { Coefficients }\end{array}$} & $\begin{array}{r}\text { Standardized } \\
\text { Coefficients }\end{array}$ & & \\
\cline { 2 - 4 } Model & \multicolumn{1}{|c|}{$\mathrm{B}$} & Std. Error & \multicolumn{1}{c|}{ Beta } & \multicolumn{1}{c|}{$\mathrm{T}$} & \multicolumn{1}{c|}{ Sig. } \\
\hline $1 \quad \begin{array}{l}\text { (Constant) } \\
\text { Interaksi X5 } \\
* \mathrm{Z}\end{array}$ & 17.321 & 1.296 & & 13.361 & .000 \\
\hline
\end{tabular}

Sumber: Data Primer diolah dengan SPSS Th.2018

Berdasarkan hasil analisis regresi linear tahap II diperoleh persamaan sebagai berikut:

$$
\begin{aligned}
& Y=\alpha+\beta_{5} X_{5} * Z \\
& Y=13,314+-0,031 X_{5} * Z
\end{aligned}
$$

Dari persamaan variabel moderasi diketahui nilai $\mathrm{t}$ hitung interaksi Tangible dengan Kepuasan sebesar -0,005 dengan nilai signifikan yaitu 0,963. Dapat disimpulkan bahwa variabel Kepuasan memperlemah hubungan antara Tangible dengan Loyalitas Pasien.

\section{Uji Hipotesis}

Uji F

Uji F dilakukan untuk mengetahui variabel independen yaitu Reliability, Responsiveness, Emphaty, Assurance, Tangible secara bersama-sama mempengaruhi variabel dependen. Hasil pengujian hipotesis dengan menggunakan uji $\mathrm{F}$ dapat terlihat pada tabel 4.30 sebagai berikut: 
Tabel 5

Hasil Analisis Uji F

ANOVA $^{b}$

\begin{tabular}{|ll|r|r|r|r|r|}
\hline \multicolumn{2}{|l|}{ Model } & \multicolumn{1}{|c|}{$\begin{array}{l}\text { Sum of } \\
\text { Squares }\end{array}$} & df & Mean Square & F & Sig. \\
\hline 1 & Regression & 10.544 & 5 & 2.109 & .400 & $.847^{\mathrm{a}}$ \\
& Residual & 495.016 & 94 & 5.266 & & \\
Total & 505.560 & 99 & & & \\
\hline
\end{tabular}

Sumber: Data Primer diolah dengan SPSS Th.2018

Berdasarkan hasil pengolahan data pada tabel 4.30 terlihat bahwa nilai $\mathrm{F}$ sebesar 8,706 dan nilai signifikan $\mathrm{F}$ untuk variabel Reliability, Responsiveness, Emphaty, Assurance, Tangible sebesar 0,000. Hal ini berarti signifikan $F$ lebih kecil dari 0,05 ini menunjukkan ada pengaruh positif dan signifikan antara Reliability, Responsiveness, Emphaty, Assurance, Tangible terhadap loyalitas Pasien.

\section{Uji T}

Uji $\mathrm{T}$ dilakukan untuk melihat apakah ada pengaruh yang signifikan atau tidak secara parsial antara Kualitas Pelayanan terhadap Loyalitas pasien Adapun hasilnya dapat dilihat pada tabel 4.31

\section{Tabel 6}

Hasil Analisis Uji T

Coefficients $^{\mathbf{a}}$

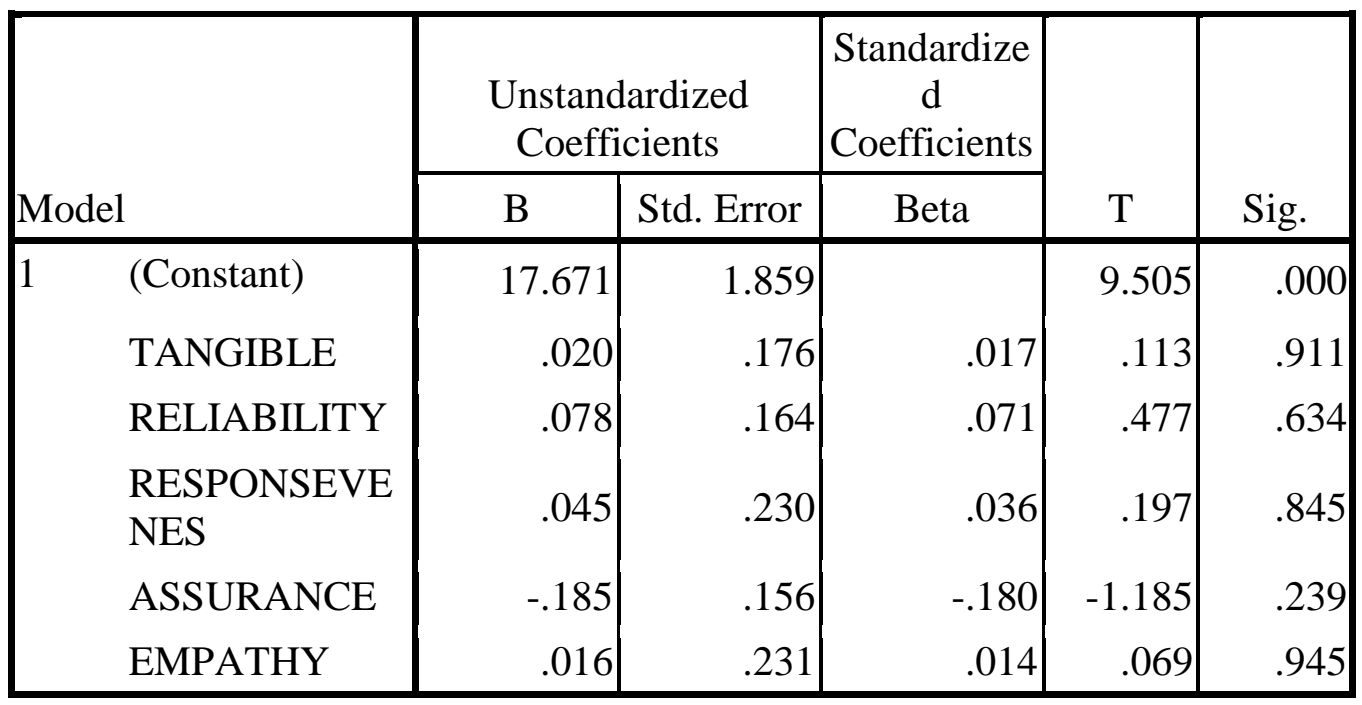

Sumber: Data Primer diolah dengan SPSS Th.2018

Berdasarkan hasil pengolahan data diatas pada tabel hasil uji $\mathrm{t}$ parsial, maka dapat disimpulkan bahwa:

a. Dari tabel diatas terlihat bahwaTangible memiliki nilai koefisien regresi negatif dengan nilai t hitung sebesar 0,133 dengan nilai sig sebesar 0,911. Jika dibandingkan dengan ( $\mathrm{t}$ tabel, sig 0.05, df (1007) =93). Maka dapat terlihat bahwa dengan nilai thitung $0,133>t$ tabel 1,661, dan nilai sig 0,911>0.05, maka dapat disimpulkan 
bahwa Ha diterima dan Ho ditolak artinya bahwa Reliabilitytidak berpengaruh dan tidak signifikan terhadap loyalitas pasien.

b. Dari tabel diatas terlihat bahwa Responsivenes memiliki nilai koefisien regresi positif dengan nilai $\mathrm{t}$ hitung sebesar 0,447 dengan nilai sig sebesar 0,634 . Jika dibandingkan dengan ( $\mathrm{t}$ tabel, sig 0.05, df $(100-7)=93)$. Maka dapat terlihat bahwa dengan nilai $\mathrm{t}$ hitung $0,447<\mathrm{t}$ tabel 1,661 dan nilai sig $0,634>0.05$, maka dapat disimpulkan bahwa Ho diterima dan Ha ditolak artinya bahwa Responsivenes tidak berpengaruh dan tidak signifikan terhadap loyalitas pasien.

c. Dari tabel diatas terlihat bahwa Emphaty memiliki nilai koefisien regresi positif dengan nilai $t$ hitung sebesar 0,36 dengan nilai sig sebesar 0,845. Jika dibandingkan dengan ( $\mathrm{t}$ tabel, sig 0.05 , df $(100-7)=93)$. Maka dapat terlihat bahwa dengan nilai $\mathrm{t}$ hitung $036<\mathrm{t}$ tabel 1,661 dan nilai sig 0,845>0.05, maka dapat disimpulkan bahwa Ho diterima dan Ha ditolak artinya bahwa Emphaty tidak berpengaruh dan tidak signifikan terhadap loyalitas Pasien.

d. Dari tabel diatas terlihat bahwa Assurance memiliki nilai koefisien regresi positif dengan nilai $t$ hitung sebesar 0,180dengan nilai sig sebesar 0,239. Jika dibandingkan dengan $(\mathrm{t}$ tabel, sig 0.05, df (100-7) = 93). Maka dapat terlihat bahwa dengan nilai $\mathrm{t}$ hitung $-0,180<\mathrm{t}$ tabel 1,666 dan nilai sig $0,239>$ 0.05, maka dapat disimpulkan bahwa Ho diterima dan Ha ditolak artinya bahwa Assurance tidak berpengaruh dan tidak signifikan terhadap loyalitas Pasien.

e. Dari tabel diatas terlihat bahwa Tangible memiliki nilai koefisien regresi positif dengan nilai t hitung sebesar 0,14 dengan nilai sig sebesar 0,945. Jika dibandingkan dengan ( $t$ tabel, sig 0.05, df (75$7)=68$ ). Maka dapat terlihat bahwa dengan nilai t hitung $0,14>t$ tabel 1,6661 dan nilai sig 0,000 < 0.05, maka dapat disimpulkan bahwa Ha diterima dan Ho ditolak artinya bahwa Tangibletidak berpengaruh dan tidak signifikan terhadap loyalitas Pasien.

\section{Koefisien Determinasi R2}

Koefisien determinasi bertujuan untuk mengukur seberapa jauh kemampuan model dalam menerangkan variasi variabel dependen.

Tabel 7

Hasil Analisis Koefisien Determinasi R2

Model Summary

\begin{tabular}{|l|r|r|r|r|}
\hline Model & \multicolumn{1}{|c|}{$\mathrm{R}$} & R Square & $\begin{array}{c}\text { Adjusted R } \\
\text { Square }\end{array}$ & $\begin{array}{c}\text { Std. Error of } \\
\text { the Estimate }\end{array}$ \\
\hline 1 & $.234^{\mathrm{a}}$ & .055 & .005 & 2.79682 \\
\hline
\end{tabular}

Berdasarkan table 4.32 diatas dapat terlihat bahwa besarnya nilai R Square (dilihat dari Adjusted R square) sebesar 0,005. Hal ini berarti 5\% loyalitas nasabah dipengaruhi oleh Reliability, Responsivenes, Emphaty, Assurance, dan Tangible sedangkan sisanya 
95\% disebabkan oleh hal-hal lain yang ada diluar penelitian seperti

Kualitas Pelayanan ,perlengkapan pelayanan, dan lain-lain.

Berdasarkan hasil penelitian Kualitas pelayanan umum terhadap Loyalitas Pasien dengan Kepuasan Pasien RSUD Sungai Dareh Sebagai Varaiabel intervening pembahasan dapat diberikan sebagai berikut:

Pengujian Kualitas pelayanan umum terhadap Loyalitas Pasien dengan Kepuasan Pasien RSUD Sungai Dareh

Berdasarkan uji statistik didapatkan ada hubungan yang positif dan negatif antaraKualitas Pelayan terhadap loyalitas Pasien. Hasil penelitian didapatkan bahwa:

a. Reliabilitytidak berpengaruh dan tidak signifikan terhadap loyalitas Pasien

Reliability adalah kemampuan memberikan pelayanan yang dijanjikan dengan segera, akurat dan memuaskan. Ini berarti RSUD Sungai Dareh memberikan pelayanan yangkurang menjanjikan yang memenuhi harapan pasien dan terbentuk loyalitas bagi Pasien.

b. Responsivenestidak berpengaruh dan tidaksignifikan terhadap loyalitas Pasien.

Responsivenes adalah keinginan atau kesediaan para karyawan untuk membantu para pelanggan dan memberikan layanan dengan tanggap.Ini berarti daya tanggap yang diberikan oleh RSUD Sungai Dareh kurang mampu menciptakan loyalitas Pasien.

c. Emphatytidak berpengaruh dan tidak signifikan terhadap loyalitas pasien.

Emphaty meliputi kemudahan dalam menjalin hubungan, komunikasi yang efektif, perhatian personal, dan pemahaman atas kebutuhan kebutuhan individual para pasien.

d. Assurancetidak berpengaruh dan tidak signifikan terhadap loyalitas Pasien

Assurancemencangkup pengetahuan, kompetensi, kesopanan, dan sifat dapat di percaya yang dimiliki para karyawan, bebas dari bahaya fisik, resiko, atau keragu-raguan.Ini berarti jaminan yang diberikan RSUD Sungai Dareh kepada Pasiendan tidak mampu dipahami oleh Pasien, seperti pengetahuan dalam menjelaskan kualitas Pelayanan mengenai di rumah Sakit RSUD Sungai dareh.

e. Tangibletidak berpengaruh dantidak signifikan terhadap loyalitas Pasien.

Tangible meliputi fasilitas fisik, perlengkapan, karyawan dan sarana komunikasi.Ini berartifasilitas yang ada pada RSUD Sungai Dareh dapat menciptakan kenyamananbagi Pasiennya.

Loyalitas adalah perilaku seorang konsumen dalam membelian atau penggunaan produk atau jasa yang diulang secara terus menerus. Apabila kinerja pelayanan yang dapatkan sesuai dengan harapan konsumen maka akandiberi penilaian baik dan memuaskan sebaliknya apabila kinerja pelayanan yang didapatkan rendah maka akan diberi 
penilaian buruk oleh konsumen. Kinerja pelayanan didasarkan pada kemampuan penyedia jasa dalam memenuhi harapan konsumen secara konsisten.

Hasil penelitian ini diperkuat oleh penelitian yang dilakukan oleh (Alma, 2007) yang berjudul Analisis unsur-unsur kualitas pelayanan jasa yang dominan kaitannya dengan kepuasan dan loyalitas nasabah, diketahui bahwa tidak semua hipotesis dapat diterima, kualitas pelayanan terbukti berpengaruh terhadap kepuasan nasabah, tetapi kualitas pelayanan tidak berpengaruh positif dan signifikan terhadap loyalitas nasabah. Sedangkan kepuasan nasabah berpengaruh positifdan terhadap loyalitas Pasien.

Hasil penelitian (Agustiono, Budi, 2006) yang berjudul analisis pengaruh kualitas pelayanan jasa terhadap kepuasan dan loyalitas pasien rawat inap di Rumah Sakit St.Elisabeth Semarang membuktikan bahwa hipotesis pertama ada pengaruh kualitas pelayanan dan kepuasan pada pasien rawat inap di Rumah Sakit St.Elisabeth Semarang, Hipotesis kedua ada pengaruh kepuasan terhadap loyalitas pasien rawat inap di Rumah Sakit St.Elisabeth Semarang, dan hipotesis ketiga ada pengaruh kualitas pelayanan dan kepuasan terhadap loyalitas pasien rawat inap di Rumah Sakit St.Elisabeth Semarang.

Loyalitas adalah perilaku pembelian atau penggunaan produk atau jasa yang dilakukan secara terus menerus. Apabila kinerja pelayanan yang diterima atau dirasakan sesuai dengan harapan konsumen maka akan dinilai baik dan memuaskan dan sebaliknya apabila kinerja pelayanan yang diterima rendah maka akan dinilai buruk oleh pengguna layanan umum. Kualitas pelayanan tergantung pada kemampuan penyedia jasa dalam memnuhi harapan konsumen secara konsisten.

Kepuasan PasienIntervening hubungan antara Kualitas Pelayanan terhadap loyalitas Pasien RSUD Sungai

Berdasarkan hasil uji regresi linear tahap I diketahui bahwa:

a. Setiap peningkatan satu kesatuan Reliability maka akan mengakibatkan penurunan nilai koefisien loyalitas

b. Setiap peningkatan satu kesatuan Responsivenes maka akan mengakibatkan penurunan nilai koefisien loyalitas

c. Setiap peningkatan satu kesatuan Emphaty maka akan mengakibatkan kenaikan nilai koefisien loyalitas

d. Setiap peningkatan satu kesatuan Assurance maka akan mengakibatkan kenaikan nilai koefisien loyalitas

e. Setiap peningkatan satu kesatuan Tangible maka akan mengakibatkan kenaikan nilai koefisien loyalitas.

Dan hasil uji regresi linear tahap II dengan menggunakan intervening diketahui bahwa:

a. Kepuasan memperkuat hubungan antara Reliabilitydengan loyalitas Pasien.

b. Kepuasan memperlemah hubungan antara Responsivenes dengan loyalitas pasien 
c. Kepuasan memperkuat hubungan antara Emphatydengan loyalitas pasien.

d. Kepuasan memperlemah hubungan antara Assurance dengan loyalitas Pasien.

e. Kepuasan memperlemah hubungan antara Tangible dengan loyalitas Pasien.

Hasil penelitian ini sejalan dengan penelitian yang dilakukan

(Dewi, 2013) yang berjudul "Efek moderasi kepuasan konsumen pada pengaruh kualitas pelayanan terhadap keputusan pelayanan umum, Hasil penelitian menunjukkan bahwa variabel kepuasan konsumen tidak intervening pengaruh variable kualitas pelayanan umum, sehingga kepuasan konsumen tidak memperkuat atau memperlemah pengaruh harga dan kualitas terhadap keputusan pembelian. Dengan demikian dapat digunakan variabellain sebagai variabel intervening seperti loyalitas, pelayanan.

\section{KESIMPULAN}

Berdasarkan hasil pengujian dan pembahasan mengenai Kualitas Pelayan umum terhadap loyalitas pasien dengan kepuasaan Pasien sebagai Variabel Intervening, maka dapat ditarik kesimpulan, antara lain:

1. Dari tabel diatas terlihat bahwa Tangible memiliki nilai koefisien regresi negatif dengan nilai t hitung sebesar 0,133 dengan nilai sig sebesar 0,911. Jika dibandingkan dengan ( $\mathrm{t}$ tabel, sig 0.05,df $(100-7)=93)$. Maka dapat terlihat bahwa dengan nilai $t$ hitung $0,133>\mathrm{t}$ tabel 1,661 , dan nilai sig 0,911>0.05, maka dapat disimpulkan bahwa Ha diterima dan Ho ditolak artinya bahwa Reliability tidak berpengaruh dan tidak signifikan terhadap loyalitas pasien.

2. Dari tabel diatas terlihat bahwa Responsivenes memiliki nilai koefisien regresi positif dengan nilai t hitung sebesar 0,447 dengan nilai sig sebesar 0,634. Jika dibandingkan dengan ( $\mathrm{t}$ tabel, sig 0.05, df $(100-7)=93$ ). Maka dapat terlihat bahwa dengan nilai t hitung 0,447< t tabel 1,661 dan nilai sig 0,634>0.05, maka dapat disimpulkan bahwa Ho diterima dan Ha ditolak artinya bahwa Responsivenes tidak berpengaruh dan tidak signifikan terhadap loyalitas pasien

3. Dari tabel diatas terlihat bahwa Emphaty memiliki nilai koefisien regresi positif dengan nilai t hitung sebesar 0,36 dengan nilai sig sebesar 0,845. Jika dibandingkan dengan ( t tabel, sig 0.05, df (100-7) = 93). Maka dapat terlihat bahwa dengan nilai t hitung $036<\mathrm{t}$ tabel 1,661 dan nilai sig 0,845> 0.05, maka dapat disimpulkan bahwa Ho diterima dan Ha ditolak artinya bahwa Emphaty tidak berpengaruh dan tidak signifikan terhadap loyalitas pasien

4. Dari tabel diatas terlihat bahwa Assurance memiliki nilai koefisien regresi positif dengan nilai $\mathrm{t}$ hitung sebesar -0,180dengan nilai sig sebesar 0,239. Jika dibandingkan dengan ( $\mathrm{t}$ tabel, sig 0.05, df (100-7) = 93). Maka dapat terlihat bahwa dengan nilai $\mathrm{t}$ hitung $-0,180<\mathrm{t}$ tabel 1,666 dan nilai sig 0,239>0.05, maka dapat disimpulkan bahwa Ho diterima dan Ha ditolak artinya bahwa Assurance tidak berpengaruh dan tidak signifikan terhadap loyalitas pasien 
5. Dari tabel diatas terlihat bahwa Tangible memiliki nilai koefisien regresi positif dengan nilai t hitung sebesar 0,14 dengan nilai sig sebesar 0,945. Jika dibandingkan dengan ( $\mathrm{t}$ tabel, sig 0.05, df $(75-7)=68)$. Maka dapat terlihat bahwa dengan nilai t hitung $0,14>\mathrm{t}$ tabel 1,6661 dan nilai sig 0,945< 0.05, maka dapat disimpulkan bahwa Ha diterima dan Ho ditolak artinya bahwa Tangible idak berpengaruh dan tidak signifikan terhadap loyalitas pasien.

\section{DAFTAR PUSTAKA}

Arikunto, S. (2010). Prosedur Penelitian Suatu Pendekatan Praktek (revisi V). jakarta: Rineka Cipta.

Dewi, R. R. (2016). Pengaruh kualitas pelayanan terhadap loyalitas pasien pengguna bpjs dengan kepuasan pasien sebagai variabel. Ekonomi Manajemen Sumber Daya, 18(2), 146-156.

Erna, F. (2005). Atribut Produk Yang Dipertimbangkan Dalam Pembelian Kosmetik Dan Pengaruhnya Pada Kepuasan Konsumen Di Surabaya. Jurnal Manajemen Dan Kewirausahaan, 7, pp.139-151. https://doi.org/10.9744/jmk.7.2.pp. 139-151

Fernos, J., \& Putra, Y. E. (2019). Analisa Pengaruh Kualitas Pelayanan Terhadap Kepuasan Nasabah Pada PT. Bank Mega Syari'ah Padang. https://doi.org/10.31219/osf.io/y2baf

Irawan, D., \& Japarianto, E. (2013). Analisa Pengaruh Kualitas Produk Terhadap Loyalitas Melalui Kepuasan Sebagai Variabel Intervening Pada Pelanggan Restoran Por Kee Surabaya. Jurnal Manajemen Pemasaran, 1(2), 1-8.

Kotler, A. (2001). prinsip-prinsip pemasaran. (W. C. Kristiaji, Ed.). jakarta.

Kukuh Familiar, I. M. (2015). Management Analysis Journal Pelanggan, Pengaruh Kualitas Produk dan Kualitas Pelayanan Terhadap Loyalitas Pelanggan Melalui Kepuasan. Management Analysis Journal, 4(4), 348354.

Kusumasasti, I., \& Hadiwidjojo, A. D. (2017). Pengaruh Kualitas Produk Dan Layanan Terhadap Loyalitas Pelanggan Coffee Shop. Ekonomi Bisnis, 22 No. 2, 123-129.

Lupiyoadi, R. (2001). manajemen pemasaran jasa (pertama). Jakarta: salemba empat.

Marlius, D. Putriani, I. (2019). Kepuasan Nasabah PT. Bank Rakyat Indonesia Unit Tapan Cabang Painan Dilihat dari Kualitas Layanan Customer Service. Jurnal Pundi. Volume 3. No. 2. Hal.111-122. https://doi.org/10.31575/jp.v3i2.151 
Marlius, D. Ananda, F. (2019). Pengaruh Kualitas Pelayanan Website Akademik Terhadap Minat Kuliah di AKBP Padang. Jurnal Pundi, Vol. 03, No. 03. Hal. 191-204. https://doi.org/10.31575/jp.v3i3.190

Marlius, D. (2018). Loyalitas Nasabah Bank Nagari Syariah Cabang Bukittinggi Dilihat Dari Kualitas Pelayanan. Jurnal Pundi. Volume 1. No. 3. Hal.1222. https://doi.org/10.31575/jp.v1i3.60

Marlius, D. (2018). Pengaruh Dimensi Kualitas Pelayanan Website Akademik Terhadap Kepuasan Mahasiswa Pada STIE “KBP”. Jurnal Ipteks Terapan. $\begin{array}{lllll}\text { Volume } & 12 . & \text { No. } & 2 . & \text { Hal. }\end{array}$ http://doi.org/10.22216/jit.2018.v12i2.633

Marlius, D. RD Putra. (2018). Strategi Pengembangan Sulam Bayang. Jurnal Benefita: Ekonomi Pembangunan Manajemen Bisnis Dan Akuntansi. Volume 3. No. 2. Hal. 204-218. http://doi.org/10.22216/jbe.v3i2.3494

Marlius, D. (2017). Keputusan Pembelian Berdasarkan Faktor Psikologis Dan Bauran Pemasaran Pada PT. Intercom Mobilindo Padang. Jurnal Pundi. Volume 1. No. 1. Hal. 57-66. https://doi.org/10.31575/jp.v1i1.9

Marlius, D. (2016). Pengaruh Bauran Pemasaran Jasa Terhadap Minat Nasabah Dalam Menabung Pada Bank Nagari Cabang Muaralabuh. https://doi.org/10.31227/osf.io/vdqgx

Fernandes, Y. D., \& Marlius, D. (2018). Peranan Customer Service Dalam Meningkatkan Pelayanan Kepada Nasabah Pada PT. Bank Pembangunan Daerah Sumatera Barat Cabang Utama Padang. https://doi.org/10.31227/osf.io/wrh3p

Mulyadi, M. (2011). Penelitian Kuantitatif dan Kualitatif serta Pemikiran Dasar Menggabungkannya. Jurnal Studi Komunikasi Dan Media, 15(1), 127138.

Sekaran, U. (2006). Research Method For Business (pertama). Jakarta: salemba empat.

Pottale, B. (2016). Pengaruh Proses Rekrutmen dan Seleksi Terhadap Kinerja Karyawan Pada PT. Bank SulutGo The Influence Of The Recruitmen Process For And Selection Of The Performance Of Employess At PT. Bank SulutGo. Berkala Ilmiah Efisien, 16(4), 453-464.

Putra, Y. E., \& Aziz, N. (2019). Pengaruh Kualitas Pelayanan Dan Kepuasan Pelanggan Terhadap Loyalitas Nasabah PT. Bank Rakyat Indonesia Cabang Padang. https://doi.org/10.31219/osf.io/hcsw2 
Sugiyono. (2013). metode penelitian manajemen (keempat). Jakarta: salemba empat.

Anggara, A., \& Mayliza, R. (2019). Pengaruh Ketidakpuasan Konsumen, Karakteristik Kategori Produk HP, Terhadap Keputusan Perpindahan Merek Pada Mahasiswa Regular Program Studi Manajemen Angkatan 2014-2015 STIE “KBP” Padang. https://doi.org/10.31219/osf.io/yfuzh

Ulfa, M., \& Mayliza, R. (2019). Pengaruh Kualitas Pelayanan Dan Kepuasan Pelanggan Terhadap Loyalitas Pelanggan PDAM Kota Padang. https://doi.org/10.31219/osf.io/spmgv

Mayliza, R. (2019). Analisis Keputusan Pembelian Ulang Axis Ditinjau Dari Bauran Pemasaran Kasus Di Kota Padang. https://doi.org/10.31219/osf.io/e7xhy

Mayliza, R. (2019). Kajian Kredit Melalui Perencanaan Dan Pengendaliannya Kasus Pada PT. Bank Perkreditan Rakyat Batang Tarusan. https://doi.org/10.31219/osf.io/h3j6m

Mayliza, R. (2019). Analisis Customer Satisfaction Dan Behavioral Intention Dilihat Dari Service Quality, Food Quality Dan Price/Value Di Restoran Mc Donald's Depok. https://doi.org/10.31219/osf.io/e2jrt

Sugiyono. (2017). metode penelitian bisnis (3rd ed.). bandung: alfabeta, cv.

Umar, H. (2013). metode penelitian untuk skripsi dan tesis bisnis. jakarta: PT. Raja Grafindo.

Wahyuni, D. U. (n.d.). Pengaruh Motivasi , Persepsi dan Sikap Konsumen Terhadap Keputusan Pembelian Sepeda Motor Merek " Honda " di Kawasan Surabaya Barat, 30-37.

Widikusyanto, M. J., Nafiuddin, Isqodrin, N., Wibowo, H. A., \& Marwan, J. (2016). Jurnal Sains Manajemen Volume.2 No.2 Juni 2016. Jurnal Sains Manajemen, 2(2), 69-83.

Widjoyo, S., Hatane, P., Brahmana, R. K. M. R., Pemasaran, J. M., Petra, U. K., \& Siwalankerto, J. (2014). Pengaruh kualitas layanan dan kualitas produk terhadap kepuasan pelanggan dan loyalitas konsumen restoran happy garden surabaya. Manajemen Pemasaran, 2(1), 1-9. 